\title{
MAPPING INSTITUTIONAL LANDSCAPES: GLOBAL EFFORTS TO IMPROVE ACCESS TO WATER
}

\author{
M. LAITURI ${ }^{1} \&$ F. STERNLIEB ${ }^{2}$ \\ ${ }^{1}$ Department of Ecosystem Science and Sustainability, Colorado State University, USA. \\ ${ }^{2}$ Department of Geosciences, Colorado State University, USA.
}

\begin{abstract}
The Paul Simon Water for the Poor Act 2005, the UN Millennium Development Goals, and Water as a Human Right are all mechanisms for enhancing access to water for the world's poorest populations. However, these water policies are not integrated into a holistic framework. They are fragmented between multiple governing agencies, founded on competing ideologies for water management, and enforced through confusing regulatory structures for land tenure tenuously linked to water rights. Alternatively, this is the governing landscape that provides the basis for innovative approaches to water solutions: integrated water resource management (IWRM), collaborative partnerships, and adaptive management strategies focused on place-based solutions. This paper examines efforts to map the intersection of poverty and water focusing on access to water and sanitation. Webbased geospatial tools of global water access issues are reviewed. The US Paul Simon Water for the Poor Act 2005 (WfP Act), the human right to water and sanitation (General Assembly Resolution 64/292, 2010), the UN Millennium Development Goals (MDG) to improve access to water and sanitation (Goal 7), and the codification of water as a human right into law by specific water poor countries are spatially cross-referenced to map the institutional landscape where water policy and water need intersect. Fundamental to improved access to water and sanitation is the need for a healthy environment. We conclude our research by examining the question: how well can these policies reconcile the conflicting demands upon the socio-ecological landscape?

Keywords: geospatial tools, global water policy, hydro-social, millennium development goals, Paul Simon Water for the Poor Act.
\end{abstract}

\section{INTRODUCTION}

Water is at the nexus of the critical issues of the 21 st century: increasing population, poverty, deteriorating environments, and escalating climate change. This is evident in new policies that have been established within the past decade at a global scale including the Millennium Development Goals (MDGs) and the human right to water, as well as policy at a national scale such as the US Senator Paul Simon Water for the Poor Act of 2005 (WfP). In 2000, the UN MDGs identified water for the poor as a key aim with the goal to reduce by half the proportion of the world's population lacking safe drinking water and basic sanitation by 2015 [1]. In July 2010, the United Nations approved General Assembly resolution 64/292 that assures water and sanitation are a human right that is fundamental to an adequate standard of living and the basis for other human rights. Against the backdrop of increasing human population and climate change, the need to understand the institutional landscape in a spatial context assists in identifying areas of conflict and cooperation [2,3] and identifies institutional processes and services that address the critical development issues associated with the right to water and sanitation. Vörösmarty et al. [4] provides a global snapshot of humanity's water security, the infrastructure of water access, and the environmental condition of the natural world. The composite index of water threats integrates issues of biodiversity with social need and presents a map of regions under stress. Based on findings from these assessments, further need for thoughtful solutions that integrate engineering solutions, policy instruments, and eco-social needs is clear.

Access and allocation to safe water and sanitation address fundamental issues encompassing the socio-ecological landscape of water provisioning. Using geospatial analysis, we conduct a comparative analysis of WfP Act projects to the UN's MDG Joint Monitoring Program for Water and Sanitation indicators and national laws codifying water as a human right [e.g. Tanzania's National 


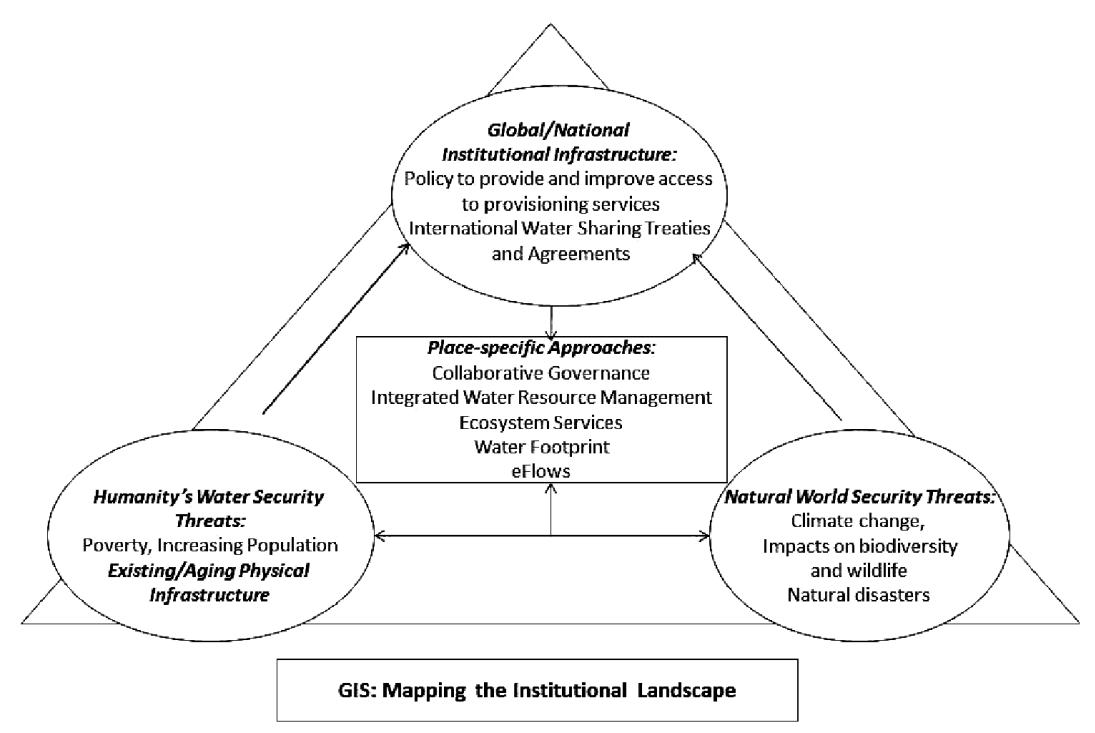

Figure 1: Triangulating environmental governance of access to water by examining global policies such as the Millennium Development Goals with social and natural needs for water for human and environmental security.

Water Law (2002), Kenya's Water Act (2002)]. We review efforts to map the physical characteristics of the geography of water (i.e. the watershed and stream network) with human population demand and institutional capacity across global scales. Efforts to formalize water as a human right hinge on the recognition that a healthy environment is essential to meeting human needs and provide an arena for alternative strategies facilitated by the framework of environmental governance. Within this context, the role of environmental governance to address both humanity and the natural world is essential. Triangulating water security threats through the global policies assists in identifying placebased approaches to improvements for water access (Fig. 1).

\section{THE GLOBAL WATER CHALLENGE, POVERTY, AND THE WFP ACT}

Galvanized by a global water movement of the first decade of the 21 st century, the human right to water has been codified in national policies and laws in many nations and adopted by the United Nations. This right is based upon the state's responsibility to ensure respect, protection, and fulfillment of the right to water [5] and emphasizes an anthropocentric view of water that does not explicitly recognize ecological rights [6]. Concurrently, efforts to protect the environment have resulted in several global environmental treaties (e.g. Convention of Biodiversity, Kyoto Protocol, Ramsar Convention on Wetlands, UN Convention on Climate Change) and numerous bilateral and regional agreements with the aim to create an environmentally sustainable future. However, there are few coincidences between these two trajectories of policy to integrate the needs of the ecological environment with the needs of society. The UN states that over 900 million people lack access to safe drinking water and that nearly 2.6 billion people lack access to basic sanitation [7]. Access to potable water and sanitation has a profound impact on both a healthy environment and livelihoods $[8,9]$. One of the major challenges in achieving the MDGs with regard to access to clean water and sanitation is improving the link between robust ecosystems and healthy human systems. Recognizing the recursive relationship between society and ecology may be implicit in global policy, but is not reflected in implementation. Explicitly recognizing societal dependence upon environments that 
provide essential services as well as requiring ecosystem rights to water is essential for future water planning that ensures adequate access and allocation of water for all.

There is a long history in the documentation of the connection between environmental protection, the human right to water, and poverty eradication as stated in the Plan of Implementation for the World Summit on Sustainable Development: 'the provision of clean drinking water and adequate sanitation is necessary to protect human health and the environment' [10]. In fact, a few of the major constraints that limit success to achieving the water and sanitation goals are ineffective governance, gender disparities, and highly variable water availability [11-13]. Since the UN Water Conference at Mar del Plata (1977), involving both women and men in the management and supply of water sanitation has been recognized as necessary and significant. International agreements and conferences (e.g. International Conference on Water and Environment, Dublin 1992) have acknowledged the central role that women play in provision, management, and safeguarding of water [14, 15]. Goal 3 of the MDGs explicitly addresses gender equality and women's empowerment [14]. The MDGs focus on increasing access to safe drinking water and basic sanitation where 'women shoulder the largest burden in collecting water' [16], linking water poverty with the disenfranchised, especially women and children. Most recently, the Millennium Declaration names 2005-2015 the International Decade for Action, Water for Life, during which the United Nations declared 2008 the International Year of Sanitation.

In conjunction with these efforts, the United States passed the WfP Act (2005) that makes reference to Goal 7, Target 10 of the United Nations MDGs, which is to reduce by half the proportion of people without access to safe drinking water by 2015 [1]. The WfP Act identifies the connection between access to safe water and sanitation to fighting hunger and poverty, gender equality, and improving the lives of slum dwellers. Situated to address global initiatives, the WfP Act amends the US Foreign Assistance Act of 1961 and the US Agricultural Trade Development and Assistance Act of 1954 making the provision of safe water and sanitation part explicit US foreign policy [1, 17]. The Senator Paul Simon Water for the World Act (proposed in 2009, 2010, and 2011) would further commit US efforts to increase access to water and sanitation by fully funding the WfP Act but remains stalled in Congressional committee.

Efforts to track the impact of these policies have led to a proliferation of reports and documents: WfP annual reports (e.g. GAO US Water and Sanitation reports; Senator Paul Simon Water for the Poor Act Report to Congress), biannual reports conducted by UN programs, JMP, UNICEF and WHO (e.g. JMP Global Water Supply and Sanitation Report; UNICEF Meeting the MDG Drinking Water and Sanitation Targets; UNEP Human Development Reports), and tracking reports conducted by various NGOs (e.g. WWF Assessing Water Risk: A Practical Approach for Financial Institutions). A key tool for assessing outcomes has been the use of interactive maps and other geospatial tools. The intersection of mapping, community capacity, and water management efforts are essential tools in monitoring and modeling for collaborative governance [18-23].

3 WHAT DO WE KNOW ABOUT GLOBAL WATER ACCESS POLICIES?

There have been several efforts to map issues related to water and human needs. Often, the term 'map' has been used as a metaphor and in fact, mapping water and institutions has largely entailed tables of data (e.g., Gleick's World's Water Biennial Report on Freshwater 1998-2008), flowcharts depicting conceptual institutional relationships [24, 25], and descriptions of governance structures $[26,27]$. However, an increasing number of projects have mapped the geography of the institutional landscape due in part to the enhanced capabilities of Geographic Information Systems (GIS), data availability from remotely sensed sources, and innovative thinking in mapping the spatial aspects of indicators and modeling efforts [4, 28, 29]. However, most of these efforts focus on the global scale, a binational or transnational scale, or a particular river basin; intermediate, transboundary, and local scales of water management are often unavailable due to a lack of data, lack of data standards 
between countries, and issues with data sharing [30, 31]. Efforts to understand the horizontal and vertical linkages [32-36] between institutional structures need to be spatially identified to determine possibilities for institutional synergy, gaps in services, and locations of conflict and cooperation.

Timelines, chronologies, databases, and maps have been developed concerning water governance and management throughout the last century. Maps as early as Hertslet's Map of Europe by Treaty (1909) were developed to demonstrate international agreements over space [37]. During the first decade of this century, a number of studies on mapping the hydropolitical landscape in a geospatial context have been conducted. The Conflict and Peace Databank [2] is one of the earliest projects compiling a global dataset on political conflict contributing to understanding of shared waterways. The Atlas of Freshwater Agreements [3, 38], a comprehensive assessment on transboundary waters, presents a historical overview of approximately 300 freshwater agreements with thematic maps of river basins and treaty boundaries. The Organization for Economic Cooperation and Development (OECD) has undertaken a survey on water governance with the purpose to coordinate multilevel governance in the water sector where 'water institutional mapping' is one of the main activities [25]. Table 1 provides some additional examples of web-based efforts to map issues related to water agreements, tracking the MDGs, water resources by country, and mapping indicators for water insecurity, poverty, and water access. Included in the table are examples of efforts to map indicators related to water (i.e. households with year-round access to improved water sources, access to sanitation facilities, cost of water supply) that assist in determining the institutional impact of improving water access by international organizations, governmental agencies, and NGOs [13, 39].

During the past decade, efforts have been consolidated to develop a more comprehensive set of water indicators that integrate physical, biological, and social data [4, 29, 40, 41]. What sets this effort apart from other schemes is that it was developed out of a collaborative, participatory effort between physical and social scientists, water managers and practitioners, and other stakeholders [42]. Reconciling differences in the spatial distribution of biogeophysical, socioeconomic, and climate variability is critical to answering questions related to human health, water conflict, and cooperation, food provisioning, water for ecosystems, and natural hazards [43]. The result of this effort is the Digital Water Atlas that demonstrates global patterns of threat due to water stress emphasizing the intersection of human and biodiversity perspectives using a spatial framework [4].

Other mapping applications include web-based approaches where non-governmental organizations have initiated projects to describe the human/water condition through the identification of projects and activities across the globe such as WaterAid's partnership with Google Maps and the World Sanitation Map [28]. The Disputed Waters Project adopts multimedia in the form of maps, stories, and photos that focus on transboundary water and conflict. Other examples include efforts to map poverty linked with biophysical conditions where water is one of many variables: Global Poverty Mapping (Center for International Earth Sciences Information Network, University of Columbia), the World Bank's research on Poverty Mapping, the United Nation's World Poverty Index, and the FAOs Food Insecurity, Poverty, and Environment Global GIS Database (FGGD). The Pacific Institute's Fusion Mapper integrates water data from around the world to share data and develop charts and graphs to better utilize global datasets, creating an 'ecosystem of data' to understand institutional services and responsibilities (e.g. economic development opportunities that support local capacity building, educational initiatives).

However, global scale assessments of water access obscure issues related to improvements for regional and local water access and availability. From 1990-2002, 1.1 billion people gained access to safe drinking water [44], yet issues related to local scale improvements of distance to water and reductions in the length of time needed to collect water remains unclear and underreported. Case studies and local-scale water projects need to be systematized to better assess local conditions and measure improved access as it is defined by global and national standards (e.g. piped water into homes, public tap, or standpipe) [7, 13, 45]. 


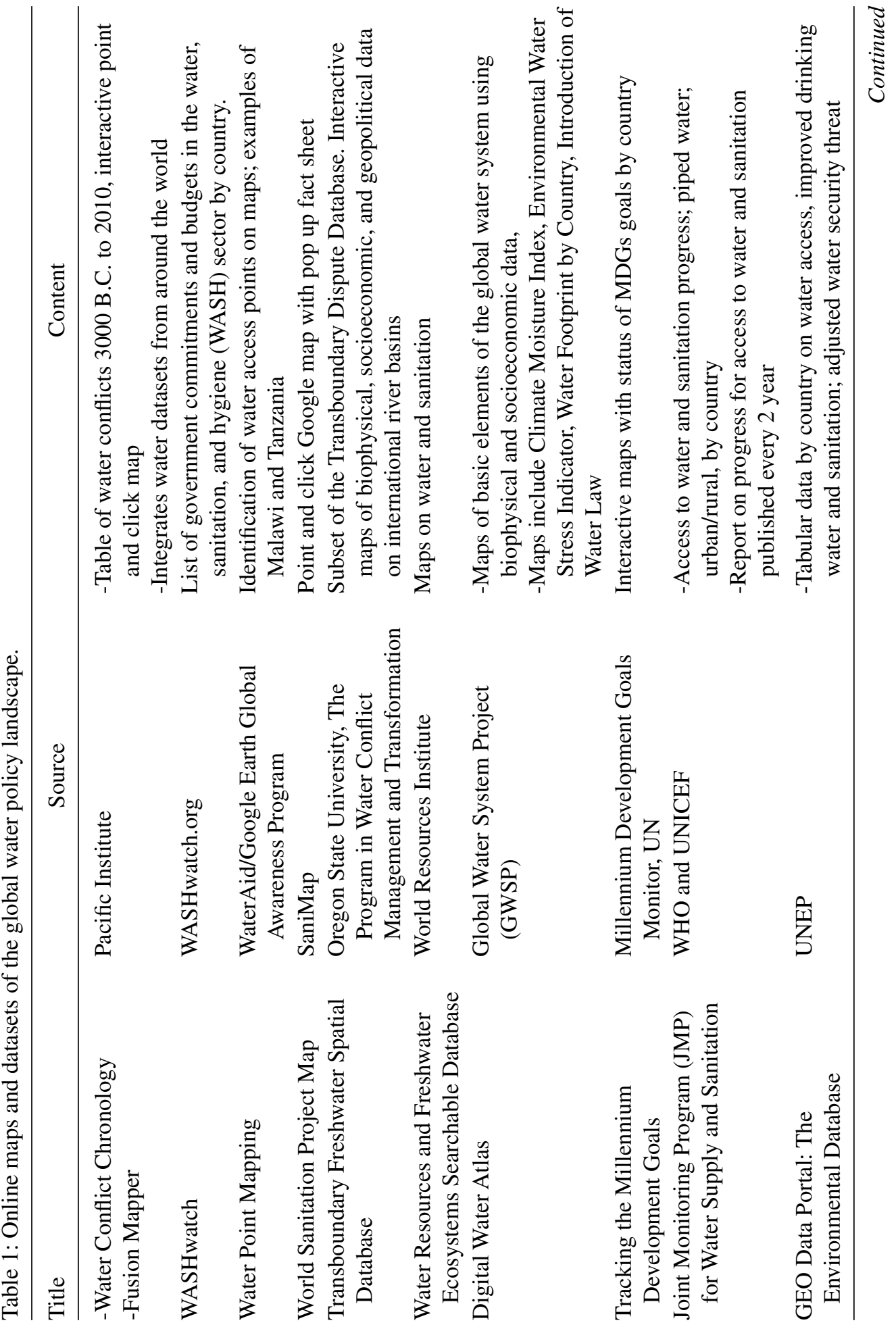




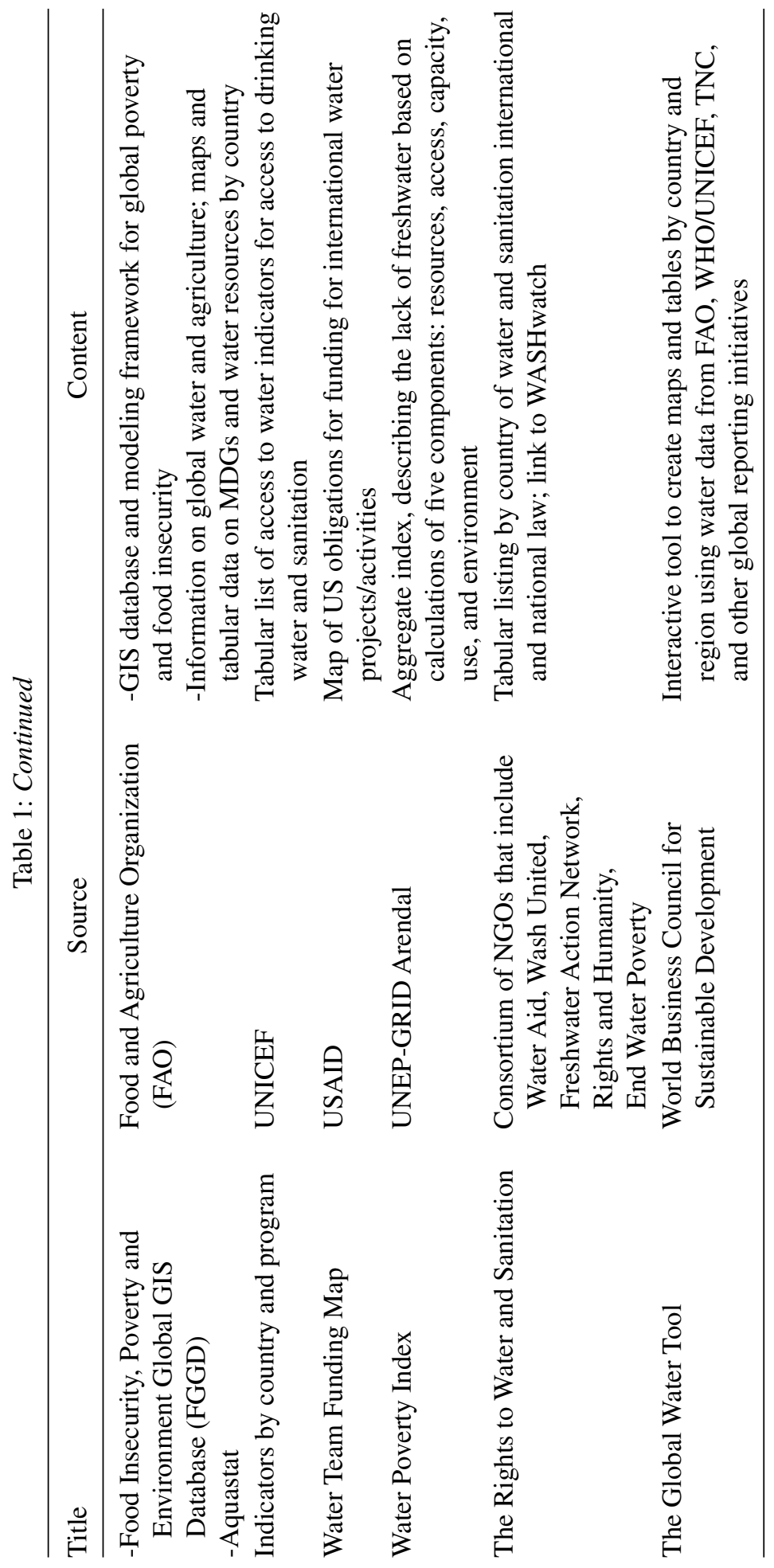




\section{SPATIAL OVERLAY OF GLOBAL WATER ACCESS INITIATIVES}

The WfP Act, the MDGs, and the human right to water initiatives and laws create a suite of powerful incentives that can be spatially overlaid to determine their global coincidence but have limited application at regional and local scales due to a lack of corresponding data. A comparison of countries that have both instituted the human right to water and projects initiated by WfP Act represents current international efforts to improve access to water at a local level. Situating this in the context of physical water stress and water access provides insights into where policies intersect at a very coarse scale. However, a complementary bottom-up assessment to cross scales both horizontally and vertically would identify the types of activities and policies that can be linked to provide further provisioning of water (Fig. 2).

The 2010 WfP Report to Congress identifies priority countries to implement key objectives, strategies, and approaches to water-related initiatives [46]. For example, sub-Saharan Africa, Asia, and the Pacific are regions that host several different scales of projects. Sub-Saharan Africa projects include: Sustainable Water and Sanitation for Africa (SUWASA) that targets 15 sub-Saharan countries; the West African Water Initiative (WAWI) in Ghana, Niger, and Mali; the Okavango Transboundary Watershed Management Program located in southwestern Africa; a water, sanitation, and hygiene movement (WASH) in central Ethiopia; and the Global Water for Sustainability (GLOWS) project in the Mara-Serengeti ecoregion. GLOWS has also recently initiated new programs in West Africa and the former Soviet Union. In Asia and the Pacific, USAID projects are embedded within the ECO-Asia Program (Environmental Cooperation). ECO-Asia projects include member states from the Association of Southeast Asian nations such as Brunei Darussalam, Cambodia, Indonesia, Lao PDR, Malaysia, Myanmar, Indonesia, Philippines, Singapore, Thailand, and Vietnam. Central activities focus on five main themes, water and sanitation, biodiversity conservation, clean development and climate, environmental governance and tsunami recovery. These

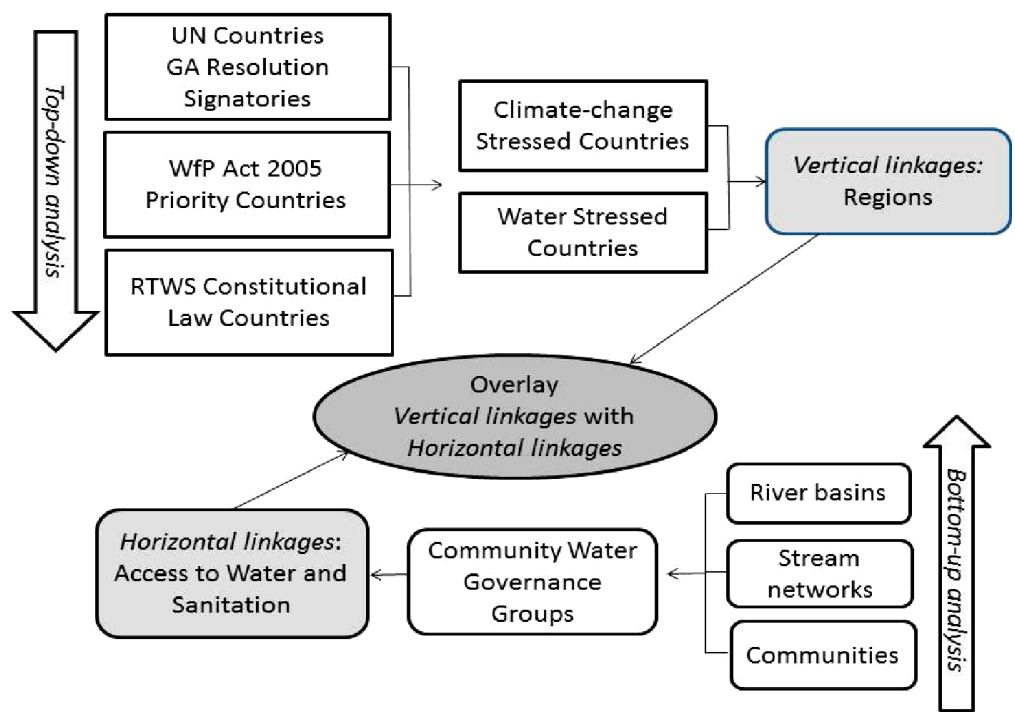

Figure 2: Cross-scale analysis where top-down and bottom-up linkages intersects to spatially identify coincident and non-coincident boundaries. UN = United Nations; GA = General Assembly; WfP = Water for the Poor; RTWS = Right to Water and Sanitation. 
projects are implemented on a variety of scales such as watersheds, regions, municipalities, and rural villages. Data for many of these projects remains sketchy and there are few maps available at a fine scale. Definition of the spatial parameters of these projects - areas impacted that include not only changes in demographics, but also the associated environments, ecosystems, and water systems - are needed to complete a spatial analysis from the bottom-up to understand socio-economic and environmental impacts.

In 2007, a study was conducted by the UN High Commissioner for Human Rights (OHCHR) requesting the official position of member nation-states on the Human Right to Water and Sanitation. Forty-two countries have either 'enshrined the right to water within their national constitutions or have framed the right explicitly within national legislation' [47]. The right to water has multiple definitions at the national scale that include the right to water, the right to sanitation, or the right to water and sanitation (Table 2, Fig. 3).

Fuelling the support for the human right to water is the UN Human Rights Council (UNHRC) adoption of a binding resolution of a human right to water (Fig. 4). The human right to water was first instituted by the United Nations Committee on Economic, Social, and Cultural Rights in General Comment 15 in November 2002. The year of 2002 was an auspicious year as this was when the Botswana government cut off access to water to Kalahari Bushmen in their ancestral homeland sparking an international response to formally adopt the right to water [50]. These UN activities build on other formal human rights doctrines including: the right to human life (1948), human health (1948), an adequate standard of living (2007), and adequate food (1999). The resolution for the Human Right To Water states: 'the human right to safe drinking water and sanitation is derived from the right to an adequate standard of living and inextricably related to the right to the highest attainable standard of physical and mental health, as well as the right to life and human dignity' [51]. This resolution represents a major victory in efforts to recognize water as a human right; however, how this resolution will be implemented remains to be seen. Several editorial documents from the UN carry this resolution a step further by contending that a healthy environment is a prerequisite of a human right to water and embedded in the intent of this resolution [52].

Table 2: Right to Water Nations.

\begin{tabular}{lc}
\hline National Policy & \multicolumn{1}{c}{ Country (Year) } \\
\hline Right to Water & Tanzania (1993), Ethiopia (1994), Mozambique (1995), Morocco (1995); \\
& $\begin{array}{l}\text { Zambia (1996); Eritrea (1997), Madagascar (1999), Belgium- specifi- } \\
\text { cally Wallonia, Flanders, Brussels (2002), Ukraine (2002), Burkina Faso }\end{array}$ \\
& (2002), Angola (2002), Uganda (2002), Kazakhstan (2003), Indonesia \\
& (2004), Namibia (2004), Costa Rica, draft (2004), Palestinian Water \\
& Authority (2006), Democratic Republic of Congo (2006), France (2006), \\
& United Kingdom (2006), Nicaragua (2007), Paraguay (2007), Venezuela \\
& (2007), Peru (2009), and Chile (2010) \\
Right to Water and & Mauritania (1991), Gambia (1996), South Africa (1997), Bangladesh (1998 \\
Sanitation & $\&$ 1999), Ecuador (1998), India (1999), Panama, Uruguay (2004), Kenya \\
& (2002), Algeria (2005), Guatemala, draft water law (2005), Sri Lanka \\
Right to Sanitation & (2007), and Bolivia, constitution currently in draft (2007) \\
& Dominican Republic (2002), Honduras, draft (2005), and Brazil (2007) \\
\hline
\end{tabular}

Source: [47, 49]. 


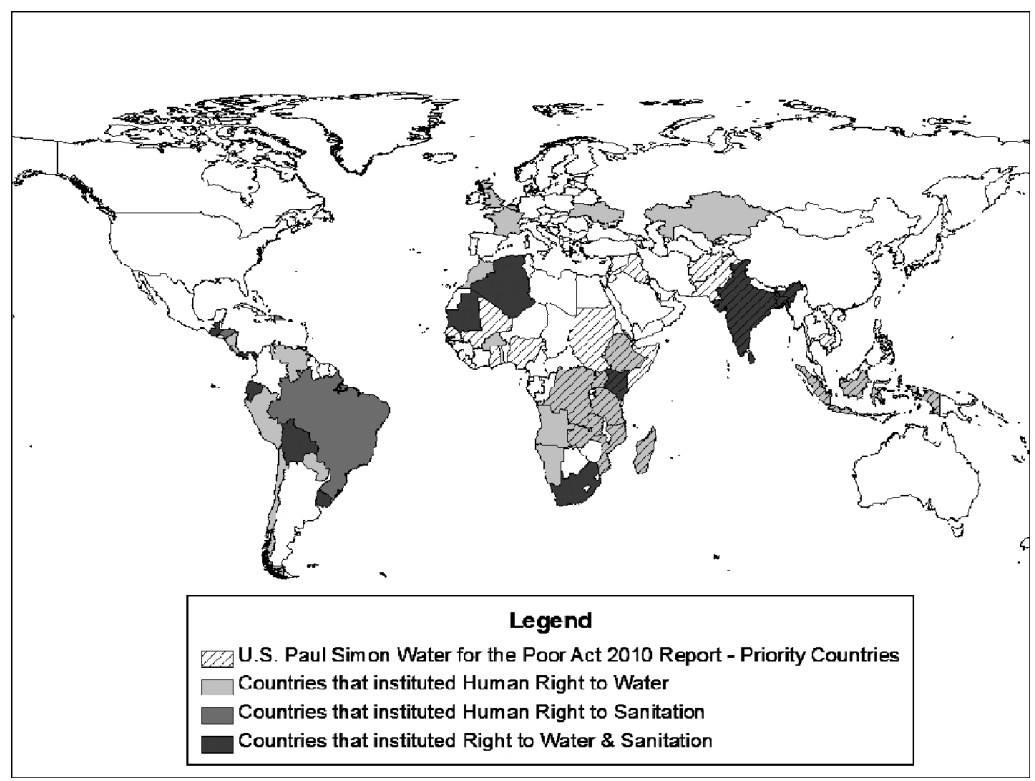

Figure 3: Priority Countries for US Paul Simon Water for the Poor and the Human Right to Water. Overlaid with WfP countries, this map depicts results from a survey by the Office of the United Nations High Commissioner for Human Rights on countries that have 'enshrined the right to water [and sanitation] within their national constitutions or have framed the right explicitly within national legislation'. [47, 48].

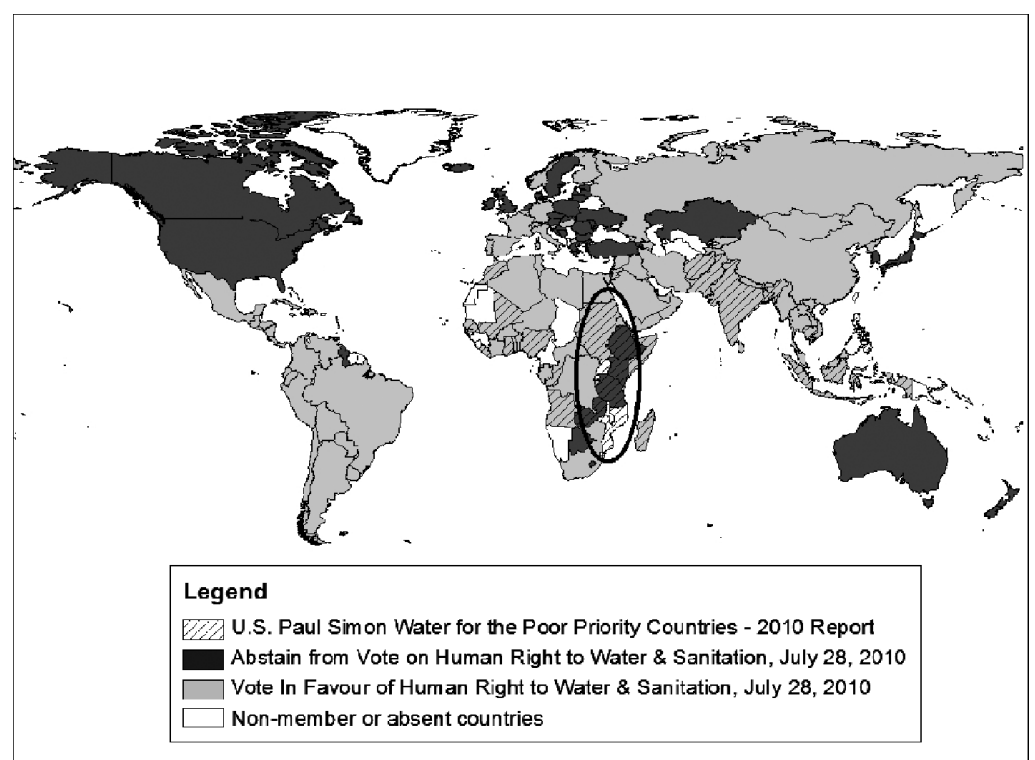

Figure 4: The United Nations Member State Vote and US Paul Simon Water for the Poor (WfP) Priority Countries. This map overlays priority countries for $\mathrm{WfP}$ and $\mathrm{UN}$ countries that voted for water as a human right -122 voted in favor and 41 abstained [51]. 

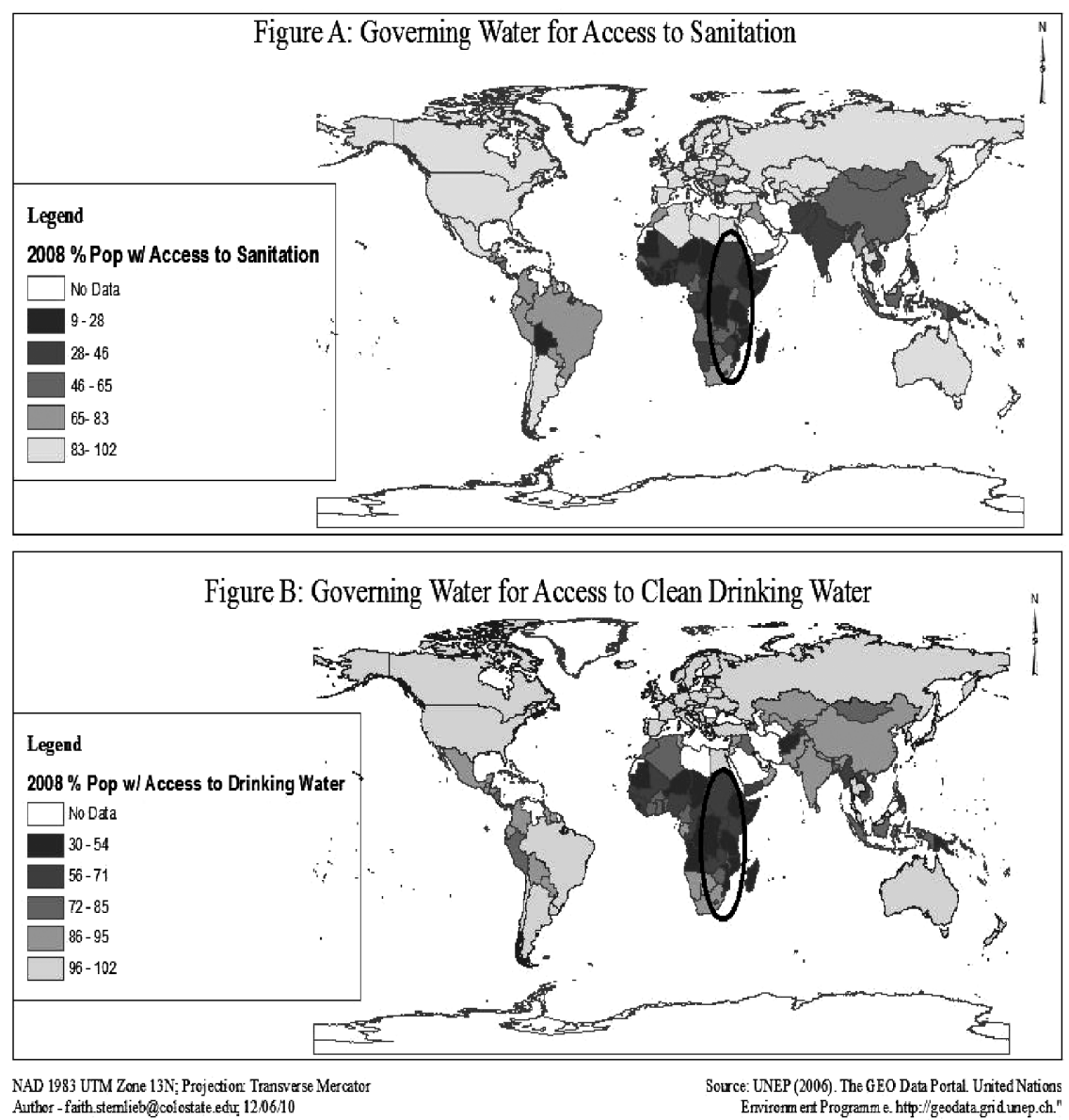

Figure 5: Comparison of the percentage of the population per country that has access to sanitation (Figure A) and clean drinking water (Figure B).

This top-down analysis indicates that there are several areas where there is a coincidence of efforts to ensure the right to water coupled with international efforts to improve access (i.e. WfP projects). The East African region is particularly important because it best demonstrates the intersection between water as a human right, the MDGs, and WfP Act initiatives (Fig. 5). Further examination of this region is critical to understand the geospatial structure of vertical linkages of institutional mechanisms to increase access to water and sanitation across scales with an emphasis on regional and local activities.

The focus of global policies of water access and provisioning are on increasing access to water and sanitation for the poor in less developed countries [1,7]. There are a variety of UN and international efforts that also focus on conservation and biodiversity issues with an emphasis on freshwater ecosystems. Increasingly, efforts are being made to integrate the two seemingly competing needs for water in scarce regions. Understanding the impacts that policies have on the capacity of the surrounding environment to support important ecosystem services such as biodiversity and wildlife migration at multiple scales is needed $[53,54]$. Human prosperity, the health of wildlife 
populations, and freshwater systems are dependent on the availability and quality of water resources, which are responsible for delivering essential ecosystem services through robust institutional mechanisms.

\section{FUTURE RESEARCH}

These maps allow us to simply demonstrate the geographic coverage globally of the human right to water linked to the MDGs and the WfP Act to improve water provisioning, data collection and sharing, and collaboration between efforts. Utilizing GIS and triangulation identifies areas of improved coverage as well as gaps in both policies and regions that are lacking institutional infrastructure, human water security, and water security for the environment. Future research will focus on collecting and identifying local data to assess adaptive local strategies that fully address the extent people are improving their access to water resources and the quality of their environment in the face of decentralization. Identifying policy by administrative boundary does not guarantee that policies are actually implemented. However, as the climate changes, linking water access strategies to environmental health is essential.

Several important lessons have emerged from this research:

- There is an increasing number of websites that distribute maps, data, and information about access to water and sanitation. The increasing amount of available data creates a confusing landscape of redundant information about water access and sanitation. Determining the definitive, authoritative source for the status on water as a human right and access to water and sanitation is difficult to navigate.

- Stated policy adopted by governments and institutions does not necessarily ensure that policy is implemented, hence, the need for indictors. Indictors are becoming increasingly sophisticated and complex, providing metrics on such nuanced issues as water poverty, water security, and water stress [13].

- Recognition of the intersection of societal and natural water needs have led to several innovative methods to access this relationship based upon material flows such as water, waste, energy, and power [55, 56]. Methods include determining the water footprint of virtual water flows [57], calculating environmental flows [58], and ecosystem services [59]. As global and national policy initiatives include language that recognizes the rights and needs of the environment, these integrated methods will become increasingly important and in need of further critical analysis and critique.

- New governance arrangements are forming in response to the decentralization strategies of water planning and management and are manifested at the local scale. Understanding and assessing the local context of water access and provisioning is needed to measure the success of such programs and determine methods for analysis between different scales that cross international boundaries and jurisdictional borders.

- The human right to water is ensnared in a contentious debate between several factions: concern over the anthropocentric nature of water as a human right [6], those who see water as an issue of human rights versus corporate rights $[50,60]$, and those who argue that human right to water would confound conservation efforts and lead to waste and biodiversity extinctions [50].

- The global water policy landscape remains confused and splintered. The 2008 'Framework for Action' to implement the WfP Act states 'water supply and sanitation service delivery are intimately connected to the sustainable management of upstream hydrologic resources that if not appropriately managed, affect the health of humans and ecosystems downstream.' However, the funding apparatus of the US federal government has resulted in creating a competition between water and sanitation and water resource planning where funding for water management has 
declined since 2000 [61, 62]. The U.S. provides on average ' 21 times as much funding per capita to the Middle East, Afghanistan, and Pakistan as it does to Sub-Saharan Africa, despite the fact that average levels of need in Sub-Saharan Africa are more than twice as high for water and sanitation' [62].

- Finally, the MDGs reflect the gargantuan task of ensuring access to water and sanitation, the aim of which is to reduce by only $50 \%$ those without access to safe drinking water and sanitation [6]. The UN Water and Sanitation Decade of 1981-1990 saw an increase in improved water supplies across the globe; however, many countries have failed to keep pace with increased population and rural to urban movements.

In reviewing the global policy landscape on water access we have identified the need to further explore the vertical linkages of global initiatives to regional and local activities. How water access plays out in specific localities reveals the success or failure of global efforts. Strengthening social rights and identifying the common good of water provisioning were keys to the near universal coverage accomplished in developed countries during the last two centuries. Recognition that the poorest members of society need different arrangements that do not fit into the dominant market-based strategies is required to identify new solutions [63]. Including these aspects within our geospatial analysis will broaden the current context for water access and sanitation and are the bases for future research. Identifying spatial linkages between social justice, water access, and community participation will identify new spaces and scales for activism and education.

\section{REFERENCES}

[1] U.S. Senate, 109th Congress, Senator Paul Simon Water for the Poor Act of 2005, http://www. wilsoncenter.org/events/docs/WFPA\%20-\%20LAW.pdf

[2] Azar, E., The conflict and peace data bank (COPDAB) project. Journal of Conflict Resolution, 24(1), pp. 143-52, 1980.

[3] Wolf, A., The transboundary freshwater dispute database project. International Water Resources Association, 24(2), pp. 160-163, 1999.

[4] Vörösmarty, C., McIntyre, P., Gessner, M., Dudgeon, D., Prusevich, A., Green, P., Glidden, S., Bunn, S., Sullivan, C., Liermann, C. \& Davies, P., Global threats to human water security and river biodiversity. Nature, 467, pp. 555-561, 2010. doi: http://dx.doi.org/10.1038/nature09440

[5] United Nations Committee on Economic, Social and Cultural Rights (UN-CESCR), General Comment No. 15, The right to water (arts.11 and 12 of the International Covenant on Economic, Social and Cultural Rights, 2002. http://www2.ohchr.org/english/issues/water/docs/ CESCR_GC_15.pdf

[6] Bakker, K., Privatizing Water: Governance Failure and the World's Urban Water Crisis, Cornel University Press: London.

[7] UN - Water Global Annual Assessment of Sanitation and Drinking Water(UN-GLAAS), 2010. http://www.who.int/water_sanitation_health/glaas/en/

[8] Hargrove, W.L., Garrity, D.P., Rhoades R.E. \& Neely, C.L., A landscape/lifescape approach to sustainability in the tropics: the experience of the SANREM CRSP at three sites (Chapter 13). Integrated Watershed Management in the Global Ecosystem, ed. R. Lal, CRC Press: Boca Raton, pp. 209-222, 2000.

[9] Deutsch, W.G., Busby, A.L., Orprecio, J.L., Bago-Labis, J.P. \& Cequina, E.Y., Communitybased hydrological and water quality assessments in Mindanao, Philippines, (Chapter 9). Forests, Water and People in the Humid Tropics, eds. M. Bonell \& L.A. Bruijnzeel, Cambridge University Press: Cambridge, pp. 134-149, 2005. 
[10] World Summit on Sustainable Development (WSSD), Plan of Implementation, 2002. http:// www.un.org/esa/sustdev/documents/WSSD_POI_PD/English/WSSD_PlanImpl.pdf

[11] Sachs, J. \& McArthur, J.W., The millennium project: a plan for meeting the millennium development goals. Lancet, 265, pp. 347-53, 2005.

[12] Fry, L.M., Mihelcic, J.R. \& Watkins, D.W., Water and nonwater-related challenges of achieving global sanitation coverage. Environmental Science \& Technology, 42, pp. 4298-4304, 2008. doi: http://dx.doi.org/10.1021/es7025856

[13] Sternlieb, F \& M. Laituri., WaSH Indicators: measuring hydro-philanthropic quality. Journal of Contemporary Water Research and Education, 145; pp. 51-60. 2009. doi: http://dx.doi. org/10.1111/j.1936-704X.2010.00082.x

[14] UNICEF, Water, Sanitation and Hygiene Annual Report. UNICEF WASH Section Programmes: New York May 2010, 2006.

[15] SANDEC \& EAWAG, Water and Sanitation in Developing Countries: Summary Report of Bellagio Expert Consultation on Environmental Sanitation in the 21 st Century, 1-4 February, Swiss Federal Institute for Environmental Science and Technology: Switzerland. 2000.

[16] United Nations Millennium Development Goals (UN MDGs), www.un.org/milleniumgoals/ environ.shtml http://www.ucowr.siu.edu/updates/145/6.pdf

[17] Sternlieb, F \& Laituri, M., Tracking political climate change: US policy and the human right to water. Water Resources Management V: Transaction Ecology and Environmen, ed. C. Brebbia, 125, pp. 624-636, 2009.

[18] Laituri, M., The issue of access: an assessment guide for evaluating public participation geographic information science case studies. Journal of the Urban and Regional Information Systems Association, 15, APA II:pp. 25-31, 2003. http://www.urisa.org/files/Laiturivol15apa2-3. pdf

[19] Laituri, M., Equity and access to GIS for marginal communities. Community Empowerment, Public Participation and Geographic Information Science, eds. W. Craig, T. Howard, \& D. Weiner, Taylor and Francis: London, pp. 270-282, 2002.

[20] Ramsey, K., A call for agonism: GIS and the politics of collaboration. Environment and Planning, 40, pp. 2346-63, 2008. doi: http://dx.doi.org/10.1068/a4028

[21] Ramsey, K., GIS, modeling and politics: on the tensions of collaborative decision support. Journal of Environmental Management, 90, pp. 1972-80, 2009. doi: http://dx.doi.org/10.1016/j. jenvman.2007.08.029

[22] Jankowski, P., Towards participatory geographic information systems for community-based environmental decision making. Journal of Environmental Management, 90, pp. 1966-71, 2009. doi: http://dx.doi.org/10.1016/j.jenvman.2007.08.028

[23] Seiber, R., Public Participation geographic information systems across borders. The Canadian Geographer, 47, pp. 50-61, 2003. doi: http://dx.doi.org/10.1111/1541-0064.02e12

[24] FAO., Rapid assessment study: Towards integrated planning of irrigation and drainage in Egypt. Final report, 2005. ftp://ftp.fao.org/docrep/fao/008/a0021e/a0021e00.pdf.

[25] Organization for Economic Co-operation and Development (OECD), Survey on Water Governance, (2009-2010). http://www.oecd.org/dataoecd/37/39/44689618.pdf

[26] Klawitter, S. \& Barghouti, I., Institutional Design and process of the Palestinian water sector: Principal stakeholder, their roles, interests and conflicts. Symposium on Sustainable Water Supply and Sanitation: Strengthening Capacity for Local Governance, September 2006, Delft, pp. 26-28, 2006.

[27] WASHCost India Team, Institutional Mapping and Analysis of WASH Services and Costs, November 2008. http://www.washcost.info/page/229 
[28] Welle, K., WaterAid learning for advocacy and good practice: WaterAid water point mapping in Malawi and Tanzania. December, 2005. http://www.wateraid.org/documents/plugin documents/waterpointmappingmalawitanzaniaweb.pdf

[29] Sullivan, C., Vörösmarty, C., Caswell, E., Bunn, S., Cline, S., Heidecke, C., Storegard, A., Proussevitch, A., Douglas. E., Bossio. D., Günther, D., Giacomello, A., O’Regan, D. \& Meigh, J., Mapping the links between water, poverty and food security. Report on the Water Indicators workshop held at the Centre for Ecology and Hydrology, Wallingford, UK, 16-19 May, 2005. GWSP Issues in GWS Research, No.1. GWSP IPO, Bonn. 2006. Available from www.gwsp.org.

[30] Committee on Assessment of Water Resources Research, National Research Council. Confronting the nation's water problems: the role of research, National Academies Press: Washington D.C., 2004.

[31] Gleick, P., The human right to water. Water Policy, 1, pp. 487-503, 1998. doi: http://dx.doi. org/10.1016/S1366-7017(99)00008-2

[32] Ostrom, E., Understanding Institutional Diversity, Princeton University Press: Princeton, 2005.

[33] Ostrom, E., Governing the Commons: The Evolution of Institutions for Collective Action, Cambridge University Press: New York, 1990.

[34] Berkes, F., Cross-scale institutional linkages: Perspectives from the bottom up (Chapter 9), The Drama of the Commons. Committee on the Human Dimension of Global Change, eds. E. Ostrom, T. Dietz, N. Dolsak, P.C. Stern, S. Stovich \& E.U.Weber, Division of Behavioral and Social Sciences and Education, National Academy Press: Washington, DC, pp. 293-322, 2002.

[35] Heikkila, T., Schlager, E., Davis, M., The role of cross-scale linkages in common pool resource management: assessing interstate river compacts. Presented at Workshop on the Institutional Analysis and Development Framework, School of Public Affairs: UC-Denver, 2010.

[36] Cash, D., Adger, W., Berkes, F., Garden, P., Lebel, L., Olsson, P., Pritchard, L., \& Young, O., Scale and cross-scale dynamics: governance and information in a multilevel world. Ecology and Society, 11(2), p. 8, 2006.

[37] Alexander, L.M., Boggs,Samuel Whittemore - an Appreciation. Annals of the Association of American Geographers, 48, pp. 237-243, 1958. doi: http://dx.doi.org/10.1111/j. 1467-8306.1958.tb01578.x

[38] Giordano, M. \& Giordano, M. \& Wolf, A., The geography of water conflict and cooperation: internal pressures and international manifestations. The Geographical Journal, 168(4), pp. 293-312, 2002. doi: http://dx.doi.org/10.1111/j.0016-7398.2002.00057.x

[39] USAID. Annex II: Tools and Indicators. Commodities Reference Guide, 2006. http://www. usaid.gov/our_work/humanitarian_assistance/ffp/crg/annex-2.htm

[40] Niemeijer, D., Developing indicators for environmental policy: data-driven and theory-driven approaches examined by example. Environmental Science \& Policy, 5, pp. 91-103, 2002. doi: http://dx.doi.org/10.1016/S1462-9011(02)00026-6

[41] Esty, D.C., Levy, M., Srebotnjak T. \& de Sherbinin, A., Environmental Sustainability Index: Benchmarking National Environmental Stewardship. Yale Center for Environmental Law \& Policy: New Haven, pp. 1-414, 2005.

[42] Lawrence, P., Meigh, J., \& Sullivan, C., The water poverty index: an international comparison. Keele Economics Research Paper 19, Keele University: Staffordshire, UK, p 17, 2002.

[43] Vörösmarty, C.J., Douglas, E.M., Green, P. \& Revenga, C., Geospatial indicators of emerging water stress: an application to Africa. Ambio, 34, pp. 230-236, 2005.

[44] UN Water Fact Sheet, 2010. http://www.un.org/waterforlifedecade/factsheet.html. Accessed 1 May 2011. 
[45] World Health Organization and United Nations Children's Fund Joint Monitoring Programme for Water Supply and Sanitation (JMP), Progress on Drinking Water and Sanitation: Special Focus on Sanitation. UNICEF, New York and WHO, Geneva, 2008.

[46] Senator Paul Simon Water for the Poor Act (WfP), Report to Congress, June 2010. http://www. state.gov/documents/organization/146141.pdf

[47] United Nations Office of the High Commissioner for Human Rights (UN OHCHR), www. unhchr.ch/development/poverty-02.html__OHCHR (Office of the High Commissioner for Human Rights), http://www2.ohchr.org/english/issues/water/contributions.htm

[48] The Right to water and Sanitation. http://www.righttowater.info/progress-so-far/national-legislation-on-the right-to water/

[49] Center on Housing Rights and Evictions (COHRE), The significance of human rights in MDGbased policy making on water and sanitation: an application to Kenya, South Africa, Ghana, Sri Lanka and Laos. 2009. http://www.cohre.org/topics/water-and-sanitation.

[50] Workman, J., Heart of Dryness: How the Last Bushmen Can Help Us Endure the Coming Age of Permanent Drought, Walker Books, 2009.

[51] United Nations General Assembly, GA 10967 - General Assembly adopts resolution recognizing access to clean water, sanitation as a human right. 2010. A/64/L.63/REV.1. http://www. un.org/News/Press/docs/2010/ga10967.doc.htm; http://www.un.org/News/Press/docs/2010/ gal10967.doc.htm).

[52] Fadaei, H., Human rights for human environment. UN Special, UDHR 60, December 2008, http://www.unspecial.org/UNS679/t29.html. Accessed 2 May 2011.

[53] Reid, R., Thornton, P. \& Kruska, R., Loss and fragmentation of habitat for pastoral people and wildlife in east Africa: concepts and issues. African Journal of Range \& Forage Science, 21(3), pp. 171-181, 2004. doi: http://dx.doi.org/10.2989/10220110409485849

[54] Thornton, P., Kruska, R., Henninger, N., Kristjanson, P., Reid, R., Atieno, F., Odero, A. \& Ndegwa, T., Mapping poverty and livestock in the developing world, International Livestock Research Institute: Nairobi, 2002.

[55] Harvey, D., Population, resources, and the ideology of science. Economic Geography, 50(3), pp. 256-277, 1974. doi: http://dx.doi.org/10.2307/142863

[56] Swyngedouw, E., The political economy and political ecology of the hydro-social cycle. Journal of Contemporary Water Research \& Education, 142, pp. 56-60, 2009.

[57] Hoekstra, A.Y. \& Chapagain, A.K. Globalization of Water: Sharing the Planet's Freshwater Resources, Blackwell Publishing: Oxford, UK, 2008.

[58] Dyson, M., Bergkamp, G. \& Scanlon, J., Flow: the essential of environmental flows, IUCN, Water and Nature Initiative: Gland, Switzeland, 2003.

[59] Millennium Development Assessment, Chapter 7: Freshwater Ecosystem Services, 2005. http://www.maweb.org/documents/document.312.aspx.pdf.

[60] Barlow, M., Blue Planet Project: http://www.blueplanetproject.net/RightToWater/index.html. Accessed 8 May 2010, 2010.

[61] GAO, US Water and Sanitation Aid: Millions of Benficiaries Reported in Developing Countries, but Department of State Needs to Strengthen Strategic Approach, 2010.

[62] Keen, B., Allen, H., Water Aid. U.S. Implementation of the Senator Paul Simon Water for the Poor Act: Small Steps for a Crisis that Calls for Great Strides. 2010.

[63] World Health Organization \& UNICEF (WHO), Meeting the Mdg Drinking Water and Sanitation Target: the Urban and Rural Challenge Of The Decade, WHO Press: Geneva, 2006. 